\title{
Were knowledge management abilities of university students enhanced after creating personal blog-based portfolios?
}

\author{
Chi-Cheng Chang \\ National Taiwan Normal University, Taiwan \\ Chaoyun Liang \\ National Taiwan University, Taiwan \\ Kuo-Hung Tseng \\ Meiho University, Taiwan \\ Ju-Shih Tseng and To-Yu Chen \\ National Taiwan Normal University, Taiwan
}

\begin{abstract}
The effect of creating blog-based portfolios on knowledge management (KM) abilities among university students was examined in the present study. Participants included 43 students majoring in Multimedia and Game Science at a University in Taiwan. Students spent nine weeks creating their personal portfolios by using a blog. The $t$-test was conducted to examine the difference in KM abilities before and after creating blog-based portfolios. The results showed that students' KM abilities after creating blog-based portfolios were significantly better than before creating blog-based portfolios.
\end{abstract}

\section{Introduction}

\section{Knowledge management and its constructs}

Knowledge management (KM) is a core competence (Hitt, Ireland, \& Lee, 2000). A study done by Chen (2005) showed that KM ability was beneficial to university students' learning and professional development. A study by Carneiro (2008) revealed that KM ability had a significant effect on innovation and competitiveness. Petrides and Nodine (2003) also found that KM ability enhanced performance in the workplace. These studies demonstrated that students' KM abilities are crucial, so the question of how to enhance students' KM ability is an important task. KM involves a wide range of education and business institutions. As knowledge is a key asset, many schools are seeking better ways to transform their knowledge into effective decision-making and action. Consequently, a KM approach helps universities enhance efficiency, improve decision-making capacity, and increase overall effectiveness (Petrides \& Nodine, 2003). There are five constructs of KM, which are knowledge sharing, knowledge innovation, knowledge acquisition, knowledge application, and knowledge accumulation (Artail, 2006; Award \& Ghaziri, 2004; Hsiao \& Hu, 2007; Lee, Lee, \& Kang, 2005; Liebowitz, 2012).

Knowledge sharing can help people understand a thing: not only "what", but also "why and how". The intention of knowledge sharing includes sharing of personal knowledge, sharing of learning, and encouragement of learning. Knowledge sharing is a process of communication that requires a fine route (Kruger \& Johnson, 2010), such as speech, publication, behaviour, or other ways in which one can communicate with others (Wang, Yang, \& Huang, 2009). Furthermore, knowledge receivers can also reach the goal of knowledge sharing by observation, modelling, or reading. The intention of knowledge innovation indicates that learners can integrate knowledge through learning and reflection (Hsiao \& Hu, 2007). Learners can understand the value of knowledge by reflection and improve their knowledge innovation behaviour (Tseng, Yang, Chen, \& Tseng, 2005). Knowledge acquisition refers to the idea that students develop new knowledge and understanding through, for example, chat and discussion (Tseng, Chen, Wu, \& Lou, 2004). Marks and Lockyer (2004) found that group members were able to acquire knowledge by interaction. Hence, mutual communication and modelling among learners can be a way to acquire knowledge (Liao, Fei, \& Chou, 2008). Knowledge application is a process where learners use their existing knowledge. The intention of knowledge application is to collect data, to store and refine, and to use it continuously. Learners' works or reflections reflect knowledge application (Akç1l \& Arap, 2009; Lee, Goh, Chua, \& Luyt, 2009). Knowledge must be stored and accumulated in order to be effectively converted into long-term memory (Shih \& Huang, 2005). Knowledge accumulation is 
amassing and storing knowledge. The intention of knowledge accumulation is that complete knowledge is accumulated from existing knowledge and new knowledge.

\section{Blog-based e-portfolios and knowledge management}

\section{E-portfolios}

E-portfolios are the evidence of learning processes and outcomes that are presented, deposited, organized and accumulated by digital media. Peers are able to share their portfolios with one another through the Internet without limitations of space and limitations to the forms of the works. Learners can set learning goals, reflect, and systematically accumulate, collect, and present their works through portfolios. This process is helpful when reviewing learners' learning progress and outcomes and to provide a growth opportunity (Cavaller, 2011; Chen, Cannon, Gabrio, Leifer, Toye, \& Bailey, 2005; McMullan, 2006).

\section{Blog-based portfolios}

Blogs are one of the most important new communication web tools in recent years (Cohen \& Krishnamurthy, 2006; Ferdig \& Trammel, 2004). Currently, blogs that are implemented in education are abundant and diverse, and portfolios are one of these implementations (Chuang, 2010). E-portfolios can be created by blogs (Lin, Kuo \& Yuan, 2007; Tan, Teo, Aw, \& Lim, 2005) because a blog: (a) consists of discussion board, multimedia sharing, and a personal diary; (b) is easy to arrange and categorize; (c) and possesses a high interaction level, which becomes a strong and effective online diary tool (Chau \& Xu, 2007; Yang \& Liu, 2008). Homik and Melis (2006) found that students were able to understand classmates' thoughts through the feedback function of the blog, which was a tool that facilitated sharing and reflection. More specifically, blogs have many interactive methods that are easy to communicate and share (Chen et al., 2005; Lin, Lin, \& Hsu, 2011; Williams \& Jacobs, 2004). Blogs are also convenient for learners to create and manage portfolios (Chuang, 2010).

\section{E-portfolios and constructs of knowledge management}

Bozhko and Heinrich (2011) proposed a framework based on a concept map of e-portfolio knowledge management. Students might draw the concept map of an e-portfolio knowledge framework for managing and structuring knowledge in their e-portfolios. Unfortunately, the tool for facilitating knowledge management was a concept map, not an e-portfolio. Some studies revealed that e-portfolios might facilitate knowledge management (Budak \& Budak, 2011; Lorenzo \& Ittelson, 2005; Meyer, Abrami, Wade, Aslan, \& Deault, 2010). However, these studies did not show detailed constructs of knowledge management and were not identified by empirical research.

To explore the effect of e-portfolios on constructs of knowledge management, the relationship between activities for creating e-portfolios and constructs of knowledge management are crucial. Activities for creating e-portfolios include providing personal information, setting learning goals, writing reflections, collecting works, arranging learning content, self-assessment, peer-assessment, modelling, and feedback (Chang, Tseng, Yueh, \& Lin, 2011). What is the relationship between these activities and the constructs of KM? The effects of the activities for creating e-portfolios on KM are described in the following paragraphs.

\section{Learning goal setting and reflection}

Robinson (2006) pointed out that learning goal setting can facilitate learners' self reflection and ability to provide self-feedback, which encourages learners to enjoy sharing their work with others. Moreover, reflection can enhance learners' innovative thoughts (Metz \& Albernhe-Giordan, 2010). Therefore, learning goal setting and reflection in e-portfolios can be helpful in enhancing knowledge sharing and knowledge innovation.

According to a study conducted by Wu, Tseng, and Liu (2006), students can produce new thoughts through reflection. Reflections about students' creation of portfolios can inspire new thoughts (Coombe \& Barlow, 2004; Metz \& Albernhe-Giordan, 2010) and reach knowledge innovation. Acquired knowledge can be applied to work revisions through reflection (Akcil \& Arap, 2009). Continuous reflection might integrate and accumulate knowledge, and finally become complete knowledge (Chu, 2009). Therefore, students' reflections in portfolios are helpful in enhancing knowledge accumulation, innovation and knowledge application. 
Work revision, assessment, modelling, and feedback

With work sharing among learners, learners are able to apply new knowledge to their own work revisions (Buyukduman \& Sirin, 2010). During the process of the revision, learners can even apply new thoughts and knowledge for their works in the future. Hence, the process of work revision is helpful to knowledge innovation and application. When learners do the self-assessment or peer-assessment, they can further inspect their own and peers' learning (Chang, 2008) and apply the acquired knowledge to self-assessment and peer-assessment (Lee et al., 2009). Therefore, self-assessment and peer-assessment are helpful for knowledge application.

Lorenzo and Ittelson (2005) stated that e-portfolios might facilitate knowledge sharing. However, they did not specify what element of an e-portfolio caused the effect. Modelling on peers' portfolios is helpful for knowledge sharing and even knowledge acquisition (Fernandez \& Illera, 2009). Thus, the mutual modelling in portfolios is helpful for knowledge sharing and knowledge acquisition. With the instant feedback in e-portfolios (Cavaller, 2011), learners are more willing to share their existing knowledge with one another actively. Therefore, feedback behaviour is beneficial to knowledge sharing and knowledge acquisition.

\section{Arrangement of learning content}

According to Ho, Huang, and Wu (2009), learners can effectively apply knowledge to works through arrangement and collection of learning contents. In addition, data collection is useful to learners in knowledge accumulation and storage (Chang, 2010; Clark \& Adamson, 2009). The study of Peet et al. (2011), based on the concept of integrative learning, shows that e-portfolios might facilitate knowledge demonstration and integration. Consequently, the process of the arrangement of learning content is helpful to knowledge application and knowledge accumulation.

In summation, e-portfolios can be a tool for KM. The process of creating e-portfolios does not only enhance knowledge sharing, innovation, and application, but also increases the convenience of knowledge acquisition and accumulation, in order to improve KM.

\section{Research purpose and questions}

Can KM ability be enhanced after students create e-portfolios? Can abilities of knowledge sharing, knowledge innovation, knowledge acquisition, and knowledge accumulation be enhanced? Based on the above-mentioned research motivation and background, the purpose of the present study was to examine the effect of e-portfolios on KM ability. Research questions are listed as the following:

1. Is students' overall KM ability after creating blog-based portfolios significantly better than before?

2. Is students' knowledge-sharing ability after creating blog-based portfolios significantly better than before?

3. Is students' knowledge-innovation ability after creating blog-based portfolios significantly better than before?

4. Is students' knowledge-acquisition ability after creating blog-based portfolios significantly better than before?

5. Is students' knowledge-application ability after creating blog-based portfolios significantly better than before?

6. Is students' knowledge-accumulation ability after creating blog-based portfolios significantly better than before?

\section{Method}

\section{Participants}

Participants included 43 students majoring in Multimedia and Game Science and taking a course called Analysis of Game Industry at a University in Taiwan. There were 28 males and 15 females creating a blog-based portfolio and using it to track their learning. 
Since students majoring in Multimedia and Game Science were good in application of information and technology, they were selected to participate in the experiment. The course, Analysis of Game Industry, required students to engage in two works, which were an analysis of a case study on a game software vendor's management and an analysis of games. The features for the works were analysis and integration, which were appropriate to reflection. The presentations of the works and modelling were the requirements of the course. Therefore, the course was suitable for the implementation of e-portfolios.

\section{Research framework}

The one-group pretest/post-test design, a method of quasi-experimental research design, was conducted in the present study to examine students' KM abilities before and after the experiment. The paired-samples $t$ test was then performed to examine the differences. The qualitative analysis for the content of portfolios was also conducted. The tool for students to create portfolios was blogs. Blogs can serve as a KM tool for storing works, portfolios, and outcomes (Chuang, 2010), which was an appropriate tool for creating portfolios.

\section{Experiment}

There were three stages in the experiment, which were orientation (first week), implementation (second to eighth week), and presentation (ninth week). Students participated in the learning unit of Analysis of Game Industry three times a week. The course content included history of game development, current global game market, current game market in Asia and Taiwan, game market in China, and current mobile game market.

\section{Orientation (pretest of KM)}

The students were given an orientation about the conception and intention of portfolios by the course instructor. The instructor demonstrated how to apply for and use a blog, including posting, responding, and some related basic functions. The students then familiarised themselves with the functions of a blog. The students completed the scale of KM ability after the course.

\section{Implementation}

The course instructor taught the course and reminded students of the key points for creating portfolios. The students created their blog-based portfolios after class and engaged in the activities, such as setting learning goals, collecting data, submitting work, writing reflections, reviewing portfolios, and giving peer feedback. The students wrote down individual learning goals toward weekly course content before the class. After a week of class, the students wrote the reflection for the week and reviewed whether they achieved the goals. In addition, the students also arranged the course contents, class notes, web information, class photos, and peer discussions, and uploaded them to the blog-based portfolio. After each session (three weeks) of the work, the teacher reviewed students' blog-based portfolios and gave feedback; the students not only shared their blog-based portfolios but also reviewed peers' portfolios and provided feedback.

Presentation (post-test of KM)

The students presented their portfolio and shared their reflections on the development of the portfolio. The students completed the scale of KM ability after the course.

\section{Research instrument}

\section{Blog-based portfolios}

The blog utilized in the present study was called Station of Wretch provided by Yahoo (http://www.wretch.cc/blog/). The Station of Wretch is the most widely used blogging platform in Taiwan. It provides functions of categorization by the press of buttons, storage of individual information, mutual discussion, message, and feedback, which are the same with e-portfolios. The students are able to track and digitize complete activities, including work content, links to resources, pictures, sounds, and videos. Students can select the function of management, enter the name of an activity of a portfolio under the categorized menu, and select "add a new category" to the menu to complete the categorization, as shown in Figure 1. 


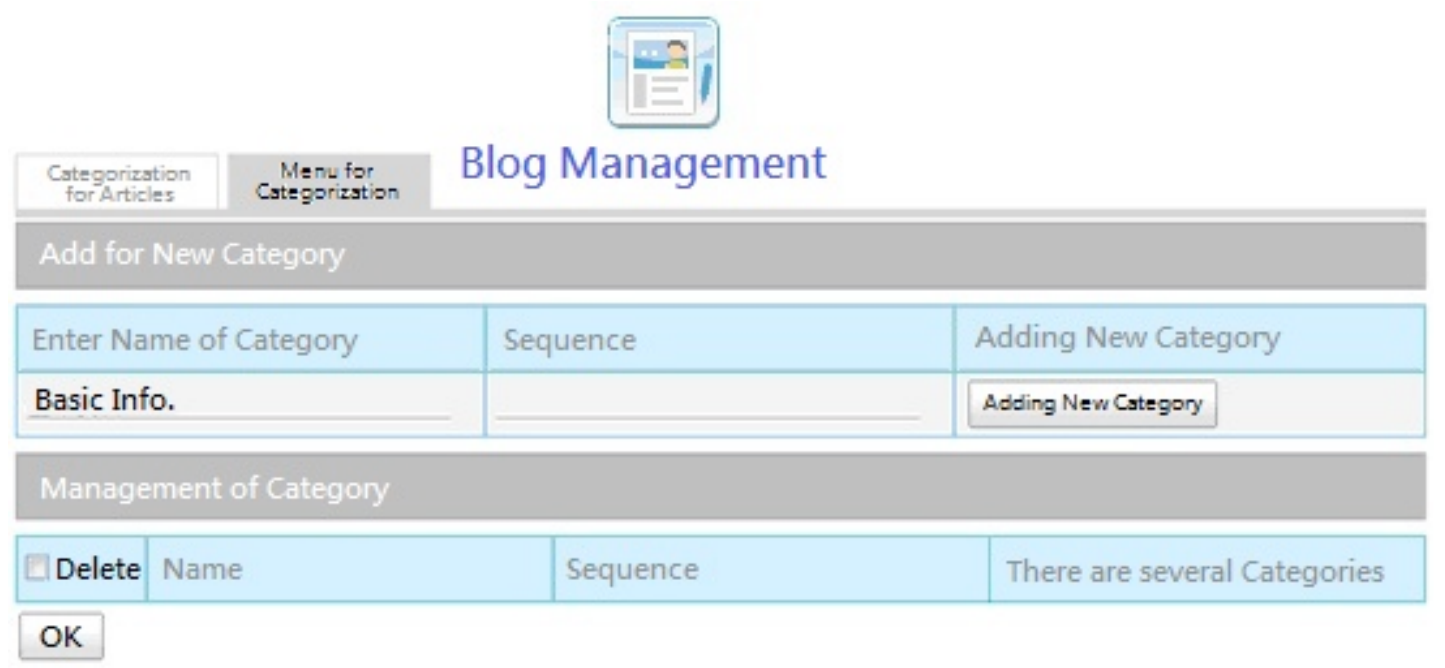

Figure 1. Management for categorization in the blog.

Items for categorization include basic information, class syllabus, learning goals, reflection of learning, related learning resources, and works, as shown in Figure 2.

\begin{tabular}{|c|c|}
\hline The Most Recent Sharing & March 24, 2011 \\
\hline Analysis of game market (reflection and goal for 7 th class) & Subject of Work: Development of OMG Company \\
\hline $\begin{array}{l}\text { Analysis of game market (reflection and goal for } 6 \text { th class) } \\
\text { [PPT presentation] Development of OMG Company }\end{array}$ & 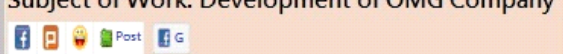 \\
\hline Learning goal for Next week (5th week)--Presentation and sharing & \\
\hline Analysis of game market (reflection and goal for 3rd class)--Trial & \\
\hline Learning goal for Next week (4th week)--Game market in Europe and America & \\
\hline Analysis of game market (reflection and goal for 2nd class)---Progress of games & \\
\hline Learning goal for Next week (4th week)--Game market in Europe and America & \\
\hline Learning goal for Next week (3rd week)--Desktop games & (Group 4) Mid-term Presentation: \\
\hline Category of Activity & Development of OMG Company \\
\hline Categury or fictivity & Analysis of SWOT \\
\hline Arrangement of relevant learning resources (2) & \\
\hline Works (1) & (Continue to read...) \\
\hline Uncategorized articles & \\
\hline
\end{tabular}

Figure 2. Options and content of blog-based portfolios.

After the last class of each week, students write down their reflections of the course. Students can use the function of discussion provided by the blog to share their thoughts and opinions with one another in order to reach the goal of interaction. Figure 3 shows reflections and feedback from students. 


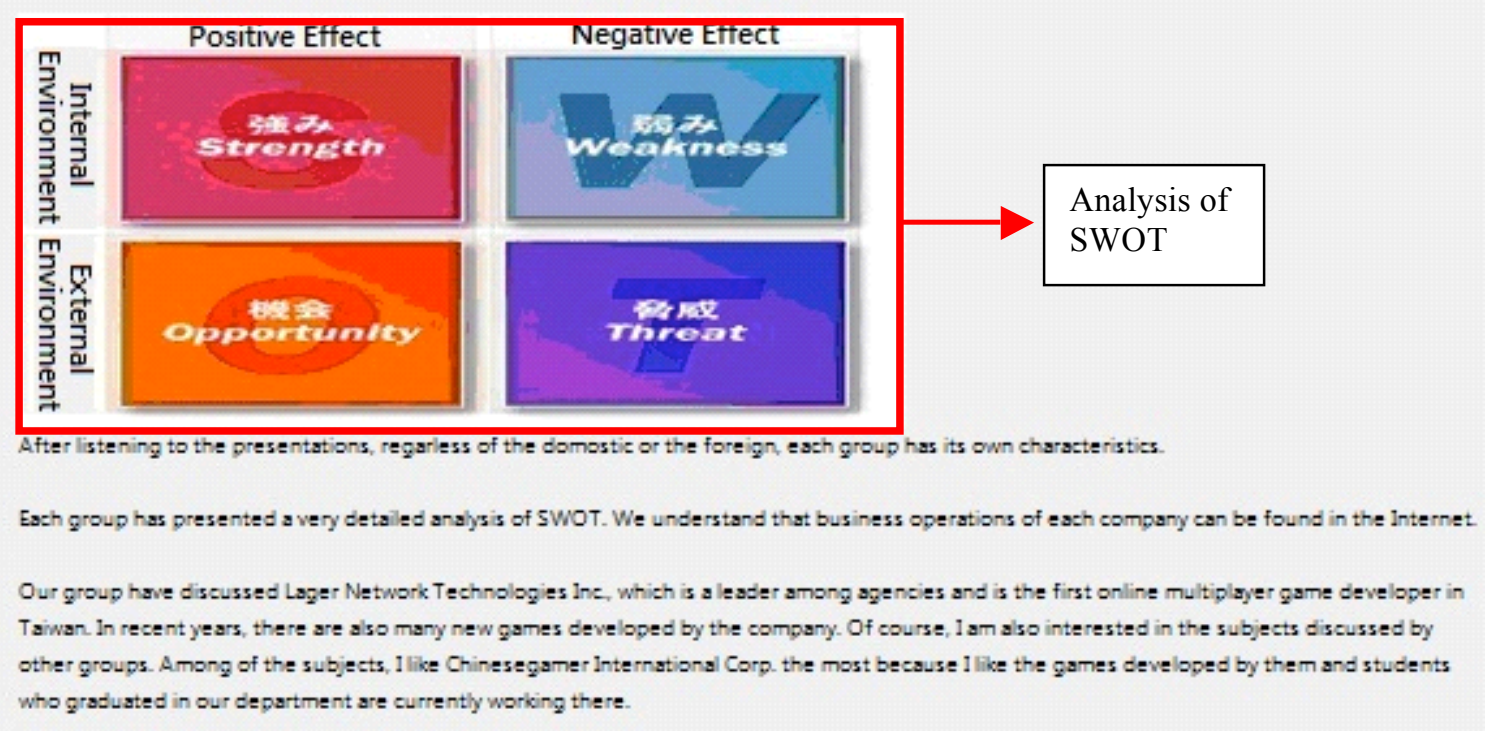

\section{comments}

After listening to the presentation provided by your group, I think Lager Network Technologies Ine has a great potentisl, and I see the

company's advantages, opportunities, dissvantages, and challenges.

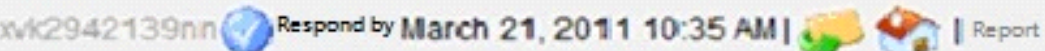

Figure 3. Students' reflections and feedback.

\section{Scale of knowledge-management ability for e-portfolios}

\section{Content}

The scale of KM ability for e-portfolios used in the present study was developed by Chang and Tsai (2012). The scale includes five constructs, which are knowledge sharing, knowledge innovation, knowledge acquisition, knowledge application, and knowledge accumulation. Each item in each construct was developed based on the activities of creating e-portfolios, including reflection, work revisions, work assessments, arrangement of learning contents (summary, notes, handouts, and web resources), peer feedback, teacher feedback, modelling, and discussion. Each construct contains eight items, so there are a total of 40 items in the scale. The measurement is based on Likert 5-point scale, ranging from 1 (strongly disagree) to 5 (strongly agree). The summary of each construct is shown as the following:

1. Knowledge sharing mainly measures learners' ability on sharing with peers. For example, I can spend time to share and discuss with peers.

2. Knowledge innovation mainly measures learners' ability on changing the way of thinking. For example, I can generate knowledge with my own thinking patterns through reflections.

3. Knowledge acquisition mainly measures learners' ability to acquire knowledge. For example, I can acquire knowledge from the arrangement of learning contents (summary, notes, handouts, and web resources).

4. Knowledge application mainly measures learners' ability on applying knowledge to works or reflections. For instance, I can apply knowledge to the reality or other situations from work revisions.

5. Knowledge accumulation mainly measures learners' ability on storing and cumulating knowledge. For instance, I can accumulate knowledge by reviewing others' works.

Item analysis

The students were categorized into the high score (top 27\%) and the low score (last 27\%) (Kelley, 1939) groups based on their final scores in the pretest. The $t$-test was conducted to examine if there are significant differences between the high-score group and the low-score group. As shown in Table 1, the result showed that critical ratios (CR) (i.e., $t$-value) for all the items were significant, which implied that the discrimination for each item in the scale was good enough. Pearson's correlation was also conducted 
for examining the relationship between each item and the scale. The result revealed that correlation coefficients were significant, which meant that each item was consistent with the whole scale.

Table 1

Item analysis

\begin{tabular}{|c|c|c|c|c|}
\hline Construct & Item & CR & Item-total correlation & Delete/Retain \\
\hline \multirow{8}{*}{$\begin{array}{c}\text { Knowledge } \\
\text { sharing }\end{array}$} & A1 & $6.304^{* * * *}$ & $0.563^{3 \times * \pi}$ & Retain \\
\hline & $\mathrm{A} 2$ & $6.412^{* * *}$ & $0.597^{* * *}$ & Retain \\
\hline & A3 & $4.810^{* * *}$ & $0.527^{* * *}$ & Retain \\
\hline & A4 & $2.290^{*}$ & $0.290^{* *}$ & Retain \\
\hline & A5 & $6.603^{* * *}$ & $0.642^{* * *}$ & Retain \\
\hline & A6 & $5.453^{* * *}$ & $0.546^{* * *}$ & Retain \\
\hline & A7 & $4.670^{* * *}$ & $0.597^{* * *}$ & Retain \\
\hline & A 8 & $4.324^{* * *}$ & $0.510^{* * *}$ & Retain \\
\hline \multirow{8}{*}{$\begin{array}{l}\text { Knowledge } \\
\text { innovation }\end{array}$} & B1 & $10.366^{* * *}$ & $0.749^{* * *}$ & Retain \\
\hline & $\mathrm{B} 2$ & $7.798^{* * *}$ & $0.695^{* * *}$ & Retain \\
\hline & B3 & $7.447^{* * *}$ & $0.713^{* * *}$ & Retain \\
\hline & B4 & $4.705^{* * *}$ & $0.514^{* * *}$ & Retain \\
\hline & B5 & $7.478^{* * *}$ & $0.626^{* * *}$ & Retain \\
\hline & B6 & $6.483^{* * *}$ & $0.573^{* * *}$ & Retain \\
\hline & B7 & $9.692^{* * *}$ & $0.770^{* * *}$ & Retain \\
\hline & B8 & $6.432^{* * *}$ & $0.622^{* * *}$ & Retain \\
\hline \multirow{8}{*}{$\begin{array}{l}\text { Knowledge } \\
\text { acquisition }\end{array}$} & $\mathrm{C} 1$ & $9.774^{* * * *}$ & $0.693^{* * *}$ & Retain \\
\hline & $\mathrm{C} 2$ & $11.987^{* * *}$ & $0.750^{* * *}$ & Retain \\
\hline & $\mathrm{C} 3$ & $5.435^{* * *}$ & $0.528^{* * *}$ & Retain \\
\hline & $\mathrm{C} 4$ & $5.046^{* * *}$ & $0.504^{* * *}$ & Retain \\
\hline & $\mathrm{C} 5$ & $6.846^{* * *}$ & $0.638^{* * *}$ & Retain \\
\hline & C6 & $7.459^{* * *}$ & $0.642^{* * *}$ & Retain \\
\hline & C7 & $8.429^{* * *}$ & $0.671^{* * *}$ & Retain \\
\hline & $\mathrm{C} 8$ & $7.598^{* * *}$ & $0.669^{* * *}$ & Retain \\
\hline \multirow{8}{*}{$\begin{array}{l}\text { Knowledge } \\
\text { application }\end{array}$} & D1 & $11.814^{* * *}$ & $0.730^{* * *}$ & Retain \\
\hline & D2 & $8.345^{* * *}$ & $0.710^{* * *}$ & Retain \\
\hline & D3 & $11.506^{* * *}$ & $0.708^{* * *}$ & Retain \\
\hline & D4 & $7.094^{* * *}$ & $0.614^{* * *}$ & Retain \\
\hline & D5 & $6.229^{* * *}$ & $0.605^{* * *}$ & Retain \\
\hline & D6 & $7.447^{* * *}$ & $0.607^{* * *}$ & Retain \\
\hline & D7 & $7.929^{* * *}$ & $0.666^{* * *}$ & Retain \\
\hline & D8 & $9.681^{* * *}$ & $0.721^{* * *}$ & Retain \\
\hline \multirow{8}{*}{$\begin{array}{l}\text { Knowledge } \\
\text { accumulation }\end{array}$} & E1 & $9.590^{* * *}$ & $0.758^{* * *}$ & Retain \\
\hline & E2 & $7.538^{* * *}$ & $0.664^{* * *}$ & Retain \\
\hline & E3 & $7.839^{* * *}$ & $0.693^{* * *}$ & Retain \\
\hline & E4 & $7.560^{* * *}$ & $0.649^{* * *}$ & Retain \\
\hline & E5 & $8.752^{* * *}$ & $0.668^{* * *}$ & Retain \\
\hline & E6 & $9.639^{* * *}$ & $0.657^{* * *}$ & Retain \\
\hline & E7 & $7.990^{* * *}$ & $0.672^{* * *}$ & Retain \\
\hline & E8 & $10.139^{* * *}$ & $0.688^{* * *}$ & Retain \\
\hline
\end{tabular}

Note. ${ }^{*} p<0.05,{ }^{* *} p<0.01,{ }^{* * *} p<0.001$

Validity

Stratified factor analysis was performed in the present study. If the conception of a construct is clear and concrete, plus items clearly belong to a certain construct, stratified factor analysis can be conducted (Hair, Black, Babin \& Anderson, 2010; Myers, Well, Lorch, \& Jr, 2010). Bartlett's Test of Sphericity and Kaiser-Meyer-Olkin measure of sampling adequacy $(\mathrm{KMO})$ were performed first. The result showed that Bartlett's test of sphericity was significant for each construct and the overall, and KMO was greater than 0.7 (closed to 0.8 ) which was acceptable (Howell, 2010). 
Principal factor analysis (PFA) with an orthogonal rotation and the largest varimax was conducted to examine the construct validity in order to avoid the overlapping of information among constructs and to easily explain factor loadings (Peers, 2007). As shown in Table 2, factor loadings for each item were greater than 0.5 , which confirmed a suggestion that items with factor loadings that are greater than 0.4 do not need to be deleted (Howell, 2010). The explained variance for each aspect was greater than $48 \%$ (note: the aspects were analysed separately, so the total explained variance could be greater than 100\%), implying that the validity of the scale was good. The eigenvalue for each construct was greater than 1 , so the existence of the five constructs was reasonable.

Table 2

Factor analysis

\begin{tabular}{|c|c|c|c|c|}
\hline Construct & Item & Eigenvalue & $\begin{array}{l}\text { Explained } \\
\text { variance }\end{array}$ & Factor loading \\
\hline \multirow{7}{*}{ Knowledge sharing } & A1 & \multirow{7}{*}{3.885} & \multirow{7}{*}{48.558} & 0.760 \\
\hline & $\mathrm{A} 2$ & & & 0.777 \\
\hline & A3 & & & 0.757 \\
\hline & A5 & & & 0.731 \\
\hline & A6 & & & 0.576 \\
\hline & A7 & & & 0.623 \\
\hline & A8 & & & 0.671 \\
\hline \multirow{8}{*}{ Knowledge innovation } & B1 & \multirow{8}{*}{4.301} & \multirow{8}{*}{53.767} & 0.814 \\
\hline & $\mathrm{B} 2$ & & & 0.798 \\
\hline & B3 & & & 0.794 \\
\hline & B4 & & & 0.625 \\
\hline & B5 & & & 0.687 \\
\hline & B6 & & & 0.657 \\
\hline & B7 & & & 0.777 \\
\hline & B8 & & & 0.687 \\
\hline \multirow{8}{*}{ Knowledge acquisition } & $\mathrm{C} 1$ & \multirow{8}{*}{3.905} & \multirow{8}{*}{48.818} & 0.726 \\
\hline & $\mathrm{C} 2$ & & & 0.846 \\
\hline & $\mathrm{C} 3$ & & & 0.649 \\
\hline & $\mathrm{C} 4$ & & & 0.589 \\
\hline & $\mathrm{C} 5$ & & & 0.673 \\
\hline & C6 & & & 0.665 \\
\hline & $\mathrm{C} 7$ & & & 0.716 \\
\hline & $\mathrm{C} 8$ & & & 0.698 \\
\hline \multirow{8}{*}{ Knowledge application } & D1 & \multirow{8}{*}{4.319} & \multirow{8}{*}{53.990} & 0.726 \\
\hline & $\mathrm{D} 2$ & & & 0.846 \\
\hline & D3 & & & 0.649 \\
\hline & D4 & & & 0.589 \\
\hline & D5 & & & 0.673 \\
\hline & D6 & & & 0.665 \\
\hline & D7 & & & 0.716 \\
\hline & D8 & & & 0.698 \\
\hline \multirow{8}{*}{$\begin{array}{l}\text { Knowledge } \\
\text { accumulation }\end{array}$} & E1 & \multirow{8}{*}{4.248} & \multirow{8}{*}{53.103} & 0.770 \\
\hline & E2 & & & 0.708 \\
\hline & E3 & & & 0.723 \\
\hline & E4 & & & 0.699 \\
\hline & E5 & & & 0.695 \\
\hline & E6 & & & 0.717 \\
\hline & E7 & & & 0.782 \\
\hline & E8 & & & 0.730 \\
\hline
\end{tabular}




\section{Reliability}

The reliability coefficients for the constructs of pre-test and post-test were greater than 0.8 and for the overall of pre-test and post-test were greater than 0.9, as measured by Cronbach's $\alpha$, suggesting that the scale had relatively high reliability

\section{Results}

\section{Differences in knowledge-management ability between pre-test and post-test}

A paired-sample $t$-test was performed to examine the differences in KM abilities between pre-test and post-test. As shown in Table 3, they were significantly different in the overall KM ability and the five constructs before and after the experiment. Students' overall KM ability and the abilities of the five constructs after creating e-portfolios were significantly better than before, which showed that the creation of blog-based portfolios had a positive effect on students' KM abilities. It is necessary to examine further effect size $d$, as shown in Table 3. The value of $d=\left|\left(\mathrm{M}_{\mathrm{e}}-\mathrm{M}_{\mathrm{c}}\right)\right| / \mathrm{S}_{\mathrm{c}}$ where $\mathrm{M}_{\mathrm{e}}=$ mean score of posttest; $\mathrm{M}_{\mathrm{c}}=$ mean score of pre-test; and $\mathrm{S}_{\mathrm{c}}=$ standard deviation of pre-test

An effect size that is smaller than 0.2 means a small relationship. An effect size that is between 0.2 and 0.5 means a small to medium relationship. An effect size that is between 0.5 and 0.8 means a medium to large relationship. An effect size that is higher than 0.2 means a large relationship (Cohen, 1988). The result revealed that blog-based portfolios had a significantly medium to high relationship with the overall KM ability and the abilities of five constructs. Blog-based portfolios had the largest relationship with knowledge innovation, and the second largest relationship with knowledge acquisition. On the other hand, blog-based portfolios had the smallest relationship with knowledge application. This showed that eportfolios had the largest effect on students' knowledge innovation, and the smallest effect on knowledge application.

Table 3

A summary of paired-sample t-test for the differences in KM ability between pretest and post-test

\begin{tabular}{ccccccccc}
\hline \multirow{2}{*}{ Construct } & \multicolumn{2}{c}{ Pre-test } & \multicolumn{2}{c}{ Post-test } & \multirow{2}{*}{$t$} & & Sig. & \multirow{2}{*}{ Effect size } \\
\cline { 2 - 5 } & Mean & SD & Mean & SD & & 0.884 & $0.006^{* *}$ & 0.506 \\
Sharing & 3.602 & 0.587 & 3.899 & 0.529 & 2.884 & 0.603 \\
Innovation & 3.709 & 0.670 & 4.113 & 0.506 & 3.529 & $0.001^{* *}$ & 0.603 \\
Acquisition & 3.756 & 0.523 & 4.032 & 0.520 & 2.429 & $0.020^{*}$ & 0.528 \\
Application & 3.649 & 0.586 & 3.942 & 0.530 & 2.586 & $0.013^{*}$ & 0.501 \\
Accumulation & 3.834 & 0.614 & 4.148 & 0.535 & 2.753 & $0.009^{* *}$ & 0.511 \\
Overall & 3.710 & 0.534 & 4.027 & 0.466 & 3.179 & $0.003^{* *}$ & 0.593 \\
\hline
\end{tabular}

Note. ${ }^{*} p<0.05, * * p<0.01$

\section{Differences in portfolio abilities before and after creating blog-based portfolios}

Table 4 shows the $t$-test of the differences in portfolio creation abilities before and after creating blogbased portfolios. The means of the post-test were significantly better than the means of the pre-test. The effect size of reflection was the greatest, revealing that blog-based portfolios had the greatest effect on the enhancement of reflection ability, which had the greatest enhancement on KM ability. 
Table 4

A summary of the t-test for the differences in portfolio abilities between pre-test and post-test

\begin{tabular}{|c|c|c|c|c|c|}
\hline \multirow{2}{*}{ Portfolio creation ability } & \multicolumn{2}{|c|}{ Mean } & \multirow{2}{*}{$t$} & \multirow{2}{*}{ Sig. } & \multirow{2}{*}{ Effect size } \\
\hline & Pre-test & Post-test & & & \\
\hline Reflection & 3.442 & 4.098 & 8.202 & $0.000 * * *$ & 1.706 \\
\hline Revision of work & 3.493 & 4.070 & 7.937 & $0.000 * * *$ & 1.576 \\
\hline Self-assessment & 3.423 & 4.014 & 6.788 & $0.000 * * *$ & 1.651 \\
\hline Arrangement of learning contents & 3.474 & 4.093 & 5.450 & $0.000 * * *$ & 1.229 \\
\hline Peer feedback & 3.442 & 3.921 & 5.836 & $0.000 * * *$ & 1.278 \\
\hline Teacher feedback & 3.539 & 3.958 & 4.104 & $0.000 * * *$ & 0.997 \\
\hline Modelling & 3.600 & 4.061 & 4.498 & $0.000 * * *$ & 1.210 \\
\hline Discussion & 3.526 & 4.014 & 4.685 & $0.000 * * *$ & 0.967 \\
\hline
\end{tabular}

Note. ${ }^{* * *} p<0.001$

\section{Discussion}

\section{Enhancement of knowledge-management ability by blog-based portfolios}

Students' KM abilities after creating blog-based portfolios were significantly better than before. This result confirmed some studies that e-portfolios can be a tool for KM (Budak \& Budak, 2011; Meyer et al., 2010). However, the study about evaluation on teaching knowledge among pre-service teachers via portfolios by Budak and Budak focused on paper-based portfolios, not e-portfolios. Meyer et al. studied the improvement of learners' basic literacy and meta-cognition by the use of e-portfolios.

\section{Knowledge sharing}

The study result showed that students' knowledge-sharing ability after creating blog-based portfolios was significantly better than before. Lorenzo and Ittelson (2005) also believed that the development of eportfolios is helpful to knowledge sharing. The viewpoint from Lorenzo and Ittelson, which was not confirmed by empirical research, is now confirmed by the present study. For example, a student mentioned in his blog-based portfolio that it is easier to share knowledge with classmates by blog-based portfolios:

By sharing the acquired knowledge in the blog, I do not only learn from others' blogs, but also provide my acquired knowledge for others as their reference and discuss in the blog. Everyone can provide his opinions through blog and integrate everyone's opinions altogether as a useful information. (Student 37)

\section{Knowledge innovation}

The study result revealed that students' knowledge-innovation ability after creating blog-based portfolios was significantly better than before. Moreover, the effect size of knowledge innovation was the greatest, which means that blog-based portfolios had the greatest effect on the enhancement of knowledgeinnovation ability. This result was consistent with the suggestion provided by Metz and AlbernheGiordan (2010), which was that e-portfolios can help learners generate new ideas and enhance their innovative thinking. However, the study by Metz and Albernhe-Giordan was with students taking a course in work design, which was different from the present study. As a student mentioned in his blogbased portfolio, one can generate new and diverse viewpoints by viewing classmates' blog-based portfolios, and one can integrate acquired knowledge in order to reach knowledge innovation by the process of reflection, as shown below: 
Writing a blog helps one to absorb acquired knowledge because one often thinks while writing. When viewing others' blogs, one can generate different thoughts and comprehension, which helps one to think differently. (Student 1)

\section{Knowledge acquisition}

The study demonstrated that students' knowledge-acquisition ability after creating blog-based portfolios was significantly better than before. Marks and Lockyer (2004) pointed out that students can acquire knowledge through interaction and communication, which was confirmed with the study result that students can acquire knowledge by communication. This statement was consistent with a student's opinion that one can acquire knowledge from interaction and communication. As the student mentioned in the blog-based portfolio:

Students who are absent due to a cold can still know what the teacher teaches by the blog.

Students still can learn even if they do not go to school for a day. (Student 8)

\section{Knowledge application}

The study found that students' knowledge-application ability after creating blog-based portfolios was significantly better than before. This finding corresponded to the finding of Lee et al. (2009) that students could apply acquired knowledge to their next piece of work or reflections on their learning through the process of creating portfolios. However, the study by Lee et al. used data from university students and graduate students, and focused on communication portfolios not blog-based portfolios. As a student stated about his blog-based portfolios, students can apply knowledge they acquired from viewing classmates' portfolios and reflection to the next work:

By viewing classmates' blogs, I can get more ideas and knowledge for the next work or writing. I think it is a useful portfolio. (Student 21)

\section{Knowledge accumulation}

The study found that students' knowledge-accumulation ability after creating blog-based portfolios was significantly better than before. Chu (2009) pointed out that knowledge should be arranged and accumulated, with continuous reflection, in order to become complete knowledge. This suggestion could be seen in the process of developing portfolios and in the students' blog-based portfolios, as shown in the following:

I think writing in blog-based portfolios definitely helps me in accumulating and storing knowledge. The teacher and the teaching assistant assigned some tasks to us, which required us to review the content carefully to see if there were relevant answers, to take notes, and to upload information to the blog-based portfolios. By doing this, I can always save the information in our blog-based portfolios and integrate classmates' information, which can help me to accumulate knowledge in the class. (Student 16)

\section{Conclusion and implication}

According to Hitt, Ireland, and Lee (2000), students' KM abilities are a core competitive ability, which is very important. Based on the study results, the development of blog-based portfolios can definitely enhance students' KM abilities. This result is meaningful to those universities promoting e-portfolios or KM.

The study results revealed that students' five abilities, including knowledge sharing, knowledge innovation, knowledge acquisition, knowledge application, and knowledge accumulation, and the overall knowledge ability after creating blog-based portfolios was significantly better than before. This meant that the students already possessed abilities in sharing reflections and pieces of work, generating thinking patterns by modelling peers' work, arranging learning content (abstracts, notes, handouts, and web resources), improving works by giving feedback to peers, storing work, and collecting information. 
Furthermore, from the process of developing portfolios, the students already had capacities for reflection, work revision, work assessment, arrangement of learning contents (abstracts, notes, handouts, and web resources), peer feedback toward works, teacher feedback toward works, modelling, and discussion. Overall, creating portfolios can enhance students' KM abilities.

The study results showed that the effect size for knowledge innovation was the greatest, indicating that the development of blog-based portfolios had the greatest effect on the enhancement of knowledge innovation. Hence, for the instructional design on the development of blog-based portfolios, one can include activities for knowledge innovation in order to maximize the effectiveness of blog-based portfolios. The effect size of knowledge application was the smallest, showing that blog-based portfolios had the smallest effect size on the enhancement of knowledge application, which should be improved and enhanced.

The study results also indicated that blog-based portfolios significantly enhanced KM ability, so portfolios can be included in learning activities of different subjects, which can enhance students' KM abilities. Moreover, blog-based portfolios had the greatest effect on knowledge innovation, so knowledge innovation can be a focus when one tries to enhance students' KM abilities. On the other hand, one can engage in an instructional design based on the e-portfolio activities that had a great effect size. For example, reflection had the greatest effect size. Therefore, reflection should be enhanced in order to facilitate knowledge-application ability. Discussion had a small effect size, so the related questions should be enhanced again.

Due to the limitation of the school, a small sample size was adopted in the present study. Moreover, the researcher in the study could only compare the results between pre-test and post-test. In the future, a control group learning without creating a portfolio can be included for the comparison. One can also examine the effects of different types of portfolios on KM ability, such as blog, webpage, PowerPoint, and so on. The present study was conducted using students enrolled in a course of game analysis, and the experiment lasted only nine weeks due to time constraints. Meaning a longitudinal study could not be performed. For portfolios, a long-run experiment would be better for studying students' learning behaviour. Thus, it is suggested that researchers in the future should focus on another course, and prolong the experiment in order to closer reflect reality.

In the present study, the students used a Yahoo blog to create a personal portfolio. Since this blog platform was not developed by the researcher, the server could not be controlled and managed by the researcher. In addition, there were also some commercial advertisements, which probably interfered with the creation of portfolios. It is suggested that researchers in the future should design a platform for the development of portfolios on their own in order to have an easy method for management. As this is an era of technological development where new and advanced technologies are emerging with each passing day, there will be more tools for portfolios or KM. Technology acts as an assistant in KM (Bain \& Swan, 2011). Therefore, it is suggested that researchers in the future should use other technology to create different types of portfolios, such as wiki-based portfolios, Facebook-based portfolios, Plurk-based portfolios, and Twitter-based portfolios, and then examine their effects on KM ability.

\section{References}

Akcil, U., \& Arap, B. (2009). The opinions of education faculty students on learning processes involving e-portfolios. Procedia - Social and Behavioral Sciences, 1(1), 395-400.

Artail, H. A. (2006). Application of KM measures to the impact of a specialized groupware system on corporate productivity and operations. Information \& Management, 43(4), 551-564.

Award, E. M., \& Ghaziri, H. M. (2004). Knowledge management. Upper Saddle River, NJ: Perason Education/Prentice Hall.

Bain, A., \& Swan, G. (2011). Technology enhanced feedback tools as a knowledge management mechanism for supporting professional growth and school reform. Educational Technology Research and Development, 58(5), 673-685. 
Bozhko, Y., \& Heinrich, E. (2011). Concept map-based framework for learner-centered knowledge management in ePortfolios. Proceedings of the 2011 11th IEEE International Conference on Advanced Learning Technologies (pp.160-162). Athens, GA: IEEE Computer Society.

Budak, A., \& Budak, I. (2011). Assessing perceptions of pre-service teachers' teacher knowledge through portfolios. Procedia - Social and Behavioral Sciences, 15(1), 1376-1380.

Buyukduman, I., \& Sirin. S. (2010). Learning portfolio (LP) to enhance constructivism and student autonomy. Procedia - Social and Behavioral Sciences, 3, 55-61.

Carneiro, A. (2000). How does knowledge management influence innovation and competitiveness? Journal of Knowledge Management, 4(2), 87 - 98.

Cavaller, V. (2011). Portfolios for entrepreneurship and self-evaluation of higher education institutions. Procedia - Social and Behavioral Sciences, 12(1), 19-23.

Chang, C. C. (2008). Enhancing self-perceived effects using Web-based portfolio assessment. Computers in Human Behavior, 24(4), 1753-1771.

Chang, C. C., \& Tsai, C. W. (2012). Developing a knowledge management behavior scale of e-portfolio based on approaches of web fuzzy delphi and fuzzy AHP. Journal of Educational Media \& Library Sciences, 50(1), 103-134.

Chang, C. C., Tseng, K. H., Yueh, H. P., \& Lin, W. C. (2011). Consideration factors and adoption of type, tabulation and framework for creating e-portfolios. Computers \& Education, 56(2), 452-465.

Chang, Y. W. (2010). Developing portfolio to assess the information literacy of elementary students. Bulletin of Educational Psychology, 41(3), 521-550.

Chau, M., \& Xu, J. (2007). Mining communities and their relationships in blogs: A study of online hate groups. International Journal of Human-Computer Studies, 65(1), 57-70.

Chen, H. L., Cannon, D., Gabrio, J., Leifer, L., Toye, G., \& Bailey, T. (2005, June). Using wikis and weblogs to support reflective learning in an introductory engineering design course. Paper presented at the 2005 American Society for Engineering Education Annual Conference \& Exposition, Portland, Oregon.

Chen, M. Y. (2005). Teachers college students' personal knowledge management and its impact on professional learning and development. Journal of Research in Education Sciences, 50(2), 181-202.

Chu, P. C. (2009). Reflections on the implementation of portfolio in library user education. Journal of Librarianship and Information Studies, 68, 66-79.

Chuang, H. H. (2010) .Weblog-based electronic portfolios for student teachers in Taiwan. Educational Technology Research and Development, 58(2), 211-227.

Clark, W., \& Adamson, J. (2009). Assessment of an ePortfolio: Developing a taxonomy to guide the grading and feedback for personal development planning. Practitioner Research in Higher Education, $3(1), 43-51$.

Cohen, E., \& Krishnamurthy, B. (2006). A short walk in the Blogistan. Computer Networks, 50(5), 615630.

Cohen, J. (1988). Statistical power analysis for the behavioral sciences (2nd ed.). Hillsdale, NJ: Lawrence Erlbaum Associates, Publishers.

Coombe, C., \& Barlow, L. (2004). The reflective portfolio: Two case studies from the United Arab Emirates. English Teaching Forum, 41(1), 26-35. 
Ferdig, R. E., \& Trammell, K. D. (2004). Content delivery in the "Blogosphere". T. H. E. Journal, 31(7), $12-20$.

Fernandez, O. L., \& Illera, L. R. (2009). Investigating university students' adaptation to a digital learner course portfolio. Computers \& Education, 52(3), 608-616.

Hair, J. F., Black, W. C., Babin, B. J., \& Anderson, R. E. (2010). Multivariate data analysis: A global perspective. New Jersey, USA: Pearson Education.

Hitt, M. A., Ireland, R. D., Lee, H. U. (2000). Technological learning, knowledge management, firm growth and performance: An introductory essay. Journal of Engineering and Technology Management, 17(3-4), 231-246.

Ho, S. J., Huang, T. C., \& Wu, Y. Y. (2009). The construction and verification of a science learning process model. Chinese Journal of Science Education, 17(1), 69-90.

Homik, M., \& Melis, E. (2006, October). Using blogs for learning logs. Paper presented at the Annual Meeting of ePortfolio 2006, Oxford, UK.

Howell, D. C. (2010). Statistical methods for psychology (7th ed.). Independence, KY: Cengage Learning.

Hsiao, C. C., \& Hu, M. C. (2007). A study for multi-level analysis of adult education workers' knowledge management abilities: An application of hierarchical linear model. Educational Review, 29, 1-36.

Kelley, T. L. (1939). The selection of upper and lower groups for the validation of test items. Journal of Educational Psychology, 30(1), 17-24.

Kruger, C. J., \& Johnson, R. D. (2010). Information management as an enabler of knowledge management maturity: A South African perspective. International Journal of Information Management, 30(1), 57-67.

Lee, C. S., Goh, D. H. L., Chua, A. K. K., \& Luyt, B. (2009). Choosing communication portfolios to accomplish tasks: The effects of individual differences. Computers \& Education, 53(4), 1167-1176.

Lee, K. C., Lee, S., \& Kang, I. W. (2005). KMPI: Measuring knowledge management performance. Information \& Management, 42(3), 469-482.

Liao, S. H., Fei, W. C., \& Chou, C. W. (2008). A study on the relationships among knowledge acquisition, knowledge transfer and innovation capability. Journal of Technology Management, 13(1), 101-134.

Liebowitz, J. (2012). Knowledge management handbook: Collaboration and social networking. Boca Raton, FL: CRC Press.

Lin, H. T., Kuo, Y. H., \& Yuan, S. M. (2007). A web-based learning portfolio framework built on blog services. Information Technology Journal, 6(6), 858-864.

Lin, M. H., Lin, C. Y., \& Hsu, P. Y. (2011). The unrealistic claims for the effects of classroom blogging on English as a second language, students' writing performance. British Journal of Educational Technology, 42(6), 148-151.

Lorenzo, G., \& Ittelson, J. (2005). An overview of e-portfolios (Educause Learning Initiative White Paper). Retrieved from http://net.educause.edu/ir/library/pdf/eli3001.pdf

Marks, A., \& Lockyer, C. (2004). Producing knowledge: The use of the project team as a vehicle for knowledge and skill acquisition for software employees. Economoic and Industrial Democracy, 25(2), 219-245. 
McMullan, M. (2006). Students' perceptions on the use of portfolios in pre-registration nursing education: A questionnaire survey. International Journal of Nursing Studies, 43(3), 333-343.

Metz, S. M. V., \& Albernhe-Giordan, H. (2010). E-Portfolio: A pedagogical tool to enhance creativity in student's project design. Procedia - Social and Behavioral Sciences, 2(2), 3563-3567.

Meyer, E., Abrami, P. C., Wade, C. A., Aslan, O., \& Deault, L. (2010). Improving literacy and metacognition with electronic portfolios: Teaching and learning with ePEARL. Computers \& Education, 55(1), 84-91.

Myers, J. L., Well, A. D., Lorch, R. F., \& Jr. (2010). Research design and statistical analysis (3rd ed.). New York: Taylor \& Francis.

Peers, I. S. (2007). Statistical analysis for education \& psychology researchers. Bristol, PA: Falmer.

Peet, M., Lonn, S., Gurin, P., Boyer, K. P., Matney, M., Marra, T., Taylor, S. H., \& Daley, A. (2011). Fostering integrative knowledge through ePortfolios. International Journal of ePortfolio, 1(1), 11-31.

Petrides, L. A., \& Nodine, T. R. (2003). Knowledge management in education: Defining the landscape. (ERIC Document Reproduction Service NO. ED 477 349). Half Moonbay, CA: Institute for the study of Knowledge Management in Education.

Robinson, S. (2006). The mission of the j-blog: Recapturing journalistic authority online. Journalism, $7(1), 65-83$.

Shih, H. A., \& Huang, J. W. (2005). The relationship between knowledge management and human resource management in Taiwanese high-tech corporations. Sun Yat-Sen Management Review, 13(4), 925-958.

Tan, Y. H., Teo, E. H., Aw, W. L., \& Lim, W. Y. (2005, May). Portfolio building in Chinese language learning using blogs. Paper presented at the BlogTalk Downunder 2005 Conference, Sydney, Australia.

Tseng, K. H., Chen, J. T., Wu, M. C., \& Lou, S. J. (2004). A study on the feasible strategies and the impeditive factors for elementary teachers to acquire knowledge of elementary: Schools in Tainan County, Taiwan. Journal of Research in Education Sciences, 49(2), 65-88.

Tseng, K. H., Yang, H. J., Chen, S. T., \& Tseng, C. H. (2005). A study on the feasible strategies and the impeditive factors to innovate knowledge for elementary teachers. Educational Review, 25, 51-78.

Wang, M. H., Yang, T. Y., \& Huang, K. C. (2009). The impact of knowledge sharing types and team learning capability on team creativity. Journal of Information Management, 16(1), 181-202.

Williams, J. B., \& Jacobs, J. (2004). Exploring the use of blogs as learning spaces in the higher education sector. Australasian Journal of Educational Technology, 20(2), 232-247. Retrieved from http://www.ascilite.org.au/ajet/ajet20/williams.html

Wu, M. C., Tseng, K. H., \& Liu, W. T. (2006). The effects of a learning experience on reasoning skills for students in postsecondary vocational education programs. Chinese Journal of Science Education, 14(4), 427-445.

Yang, H. L., \& Liu, C. L. (2008). A new standard of on-line customer service process: Integrating language-action into blogs. Computer Standards \& Interfaces, 31(1), 227-245. 
Corresponding author Chi-Cheng Chang, samchang@ntnu.edu.tw

Australasian Journal of Educational Technology (C) 2013.

Please cite as: Chang, C.-C., Liang, C., Tseng, K.-H., Tseng, J.-S., \& Chen, T.-Y. (2013). Were knowledge management abilities of university students enhanced after creating personal blog-based portfolios? Australasian Journal of Educational Technology, 29(6), 916-931. 